Piotr Stańczyk

Uniwersytet Gdański

E-MAIL: pedps@univ.gda.pl

\title{
Pedagogia możliwości w ekonomii. \\ Ladislau Dowbor, \\ Co to Za GRA? Nowe PODEJŚcia do EKONOMII, Książka i Praca, Warszawa 2017, ss. 253
}

\begin{abstract}
STRESZCZENIE
Zasadniczym celem tego tekstu jest recenzja nowej książki L. Dowbora. Co To zA GRA? jest czwartą książką tego brazylijskiego ekonomisty, ukazującą się w Polsce. Recenzja napisana jest $\mathrm{z}$ perspektywy pedagogicznej, a uwarunkowania ekonomiczne uznane są za kluczowe dla procesów edukacyjnych w ogóle, a w szczególności dla procesów edukacyjnych zorientowanych emancypacyjnie. Recenzowana książka jest wyjątkowym przykładem Freirowskiej pedagogii możliwości w dyskursie ekonomicznym.

SŁoWA KLUCzowE: demokracja ekonomiczna, ekonomia dla emancypacji, Ladislau Dowbor
\end{abstract}

Recenzowana książka L. Dowbora Co TO ZA GRA? Nowe PODEJŚcia do EKONOMII jest czwartą przetłumaczoną na język polski książką tego brazylijskiego ekonomisty polskiego pochodzenia i jednego $\mathrm{z}$ architektów reform społeczno-ekonomicznych zokresu rządów Luiza Inácio Luli da Silvy. Wcześniej ukazała się Brazylia bez Egzotyki. Formowanie SiĘ KAPITAlizmu Zależnego w BrazyliI (1981); Rozbita mozaika. EKonomia poza równaniami (2005) oraz Demokracja ekonomiczna. Alternatywne ROZWIĄZANIA W SFERZE ZARZĄDZANIA SPOŁECZNEGO (2009). Z perspektywy zawartości najnowszej książki L. Dowbora kluczowym punktem odniesienia jest Demokracja ekonomiczna jako książka i demokracja ekonomiczna jako idée fixe, organizująca wywód Autora. Mówiąc wprost, Co TO ZA GRA? jest kontynuacją projektu poszukiwania alternatywnych rozwiązań w zarządzaniu społecznym w okresie późnego kapitalizmu. Można by wręcz zaryzykować stwierdzenie, iż recenzowana książka mogłaby nosić tytuł DemoKRACJA EKONOMICZNA DZIESIĘĆ LAT PÓŹNIEJ, tylko że ta dekada, która dzieli obie książki L. Dowbora, naznaczona była przez wydarzenia gospodarcze 
bez precedensu, a chodzi oczywiście o wielki kryzys finansowy z 2008 roku, a także postępującą gwałtownie polaryzację dochodów i nagromadzonego bogactwa, która sprawiła, że bez cienia przesady można mówić o tym, iż żyjemy w czasach globalnej nierównowagi, w czasach bezwzględnej nierówności społecznej i nadciągającej katastrofy ekologicznej. Brazylijskie wydanie Demokracji eKonomicznej miało miejsce w 2008 roku, a polska jej edycja nie uwzględniała jeszcze doświadczeń dziejącego się podówczas na oczach badaczy kryzysu, natomiast Co TO ZA GRA? zawiera ustosunkowanie się Autora do wydarzeń z 2008 roku i kolejnych lat kryzysu finansowego, który przeobraził się w kryzys zadłużeniowy.

Koniecznie muszę podkreślić, iż - choć zasadniczym obszarem badawczym, w którym porusza się L. Dowbor jest ekonomia - recenzja ta będzie miała nachylenie pedagogiczne. Takie podejście jest całkowicie zgodne z założeniem Autora o przywróceniu ekonomii naukom społecznym (Dowbor, 2017, s. 187). Proponowana przeze mnie perspektywa może być uzasadniona dodatkowo na wiele sposobów, z których trzy uznaję za najbardziej znaczące. Po pierwsze, ekonomiczny wywód L. Dowbora zawsze znajduje swój punkt dojścia w codziennym ludzkim życiu, co dla pedagogów oznaczać może uznanie znaczenia procesów gospodarczych dla procesów edukacyjnych w ogóle, ale w szczególności dla konkretnych procesów edukacyjnych zachodzących w sali lekcyjnej czy wykładowej, czy w jakimkolwiek innym miejscu, w którym dzieją się procesy edukacyjne. Gospodarcze uwarunkowania po prostu mają kolosalne znaczenie dla naszego życia, a przy tym dyskurs L. Dowbora stanowi alternatywę i odtrutkę na neoliberalny dyskurs, który zadomowił się w edukacji. Drugi powód ma charakter instytucjonalny i wynika z powiązania L. Dowbora z Instituto Paulo Freire w São Paulo, gdzie od kilku lat ważnym nurtem badań edukacyjnych jest poszukiwanie alternatyw gospodarczych dla kapitalizmu, ze szczególnym uwzględnieniem idei Solidarnej Ekonomii Ludowej (Gadotti, 2009; Martins, 2008; Dowbor, 2008). Idąc tym tropem myślenia, że warunki ekonomiczne są kluczowe dla emancypacyjnych procesów edukacyjnych, konieczna staje się „ekonomia dla emancypacji” (Stańczyk, 2016). Takie zwrócenie uwagi badawczej na procesy gospodarcze nie oznacza $w$ żadnym razie deprecjacji zagadnień pedagogicznych, ale wiąże się z trzeźwą oceną sytuacji, w której ekonomia i stosunki produkcji rządzą naszym życiem, a więc jest życie gospodarcze obszarem ucisku kluczowym dla procesów emancypacyjnych i odzyskania sprawstwa. Tu pojawia się trzeci powód, dla którego pedagogiczne odczytanie recenzowanej książki ma sens - Co TO ZA GRA? na wskroś jest przesiąknięta Freirowską pedagogią możliwości (Freire, 1994; 2001), stanowiąc odpór wobec bezalternatywno- 
ści kapitalizmu. Jak pisze w recenzowanej książce L. Dowbor: „Bez wątpienia inny świat jest możliwy, ponieważ ten, który dotychczas stworzyliśmy, nie jest godny polecenia. Czas pokazać, że można zarządzać inaczej” (s. 58).

Recenzowana książka składa się ze wstępu i ośmiu rozdziałów. Wstęp zatytułowany REGUŁY GLOBALNEJ GRY: IGRZYSKA I NASZ POWSZEDNI CYRK (s. 9-17) nie jest typowym wstępem do książek naukowych, gdyż Autor nie artykułuje w nim ani celów ogólnych książki, ani szczegółowych, ani nie konstruuje tradycyjnie jej przedmiotu czy nie przedstawia jej zawartości. Wstęp jest pisany językiem nacechowanym afektywnie - nie jest to jednak żaden mankament. Wobec czego L. Dowbor „tonie w statystykach” (s. 11) czy określa siebie i czytelników „bandą konsumpcyjnych frajerów” (s. 16), przedstawiając sytuację, w której może jeszcze nie wiemy, jak bardzo jest źle, ale właściwie już wszyscy wiemy, że jest źle - że późny kapitalizm więcej problemów stwarza niż jest w stanie ich rozwiązać. Przy tym, zazwyczaj, poprzestajemy na roli widza „igrzysk”, „naszego cyrku powszedniego” - Autor zgryźliwie konstatuje: „żyjemy w cudownych czasach” (s. 10). Rozdziały od 1. do 6. są w mniejszym bądź większym stopniu nabudowane na DemoKraCjI eKonomiczneJ. Rozdział 1. INNOWACJA SPOŁECZNA I TRWAŁY ROZwój zawiera ciekawą, rozszerzoną koncepcję innowacyjności - pojęcia, które zawłaszczane jest przez neoliberalną koncepcję gospodarki opartej na wiedzy. Proponowana przez L. Dowbora innowacyjność ma za swój punkt wyjścia teoretyczne studia nad wskaźnikami rozwoju społecznego, a w punkcie dojścia odejście od quasi-biznesowego paradygmatu nowej administracji publicznej na rzecz paradygmatu „wrażliwego zarządzania” (ang. responsive governance) (s. 52-54). Rozdział 2. zatytułowany jest DeBATA o PKB: NASZE RACHUNKI SA BŁęDNE (s. 61-71) i stanowi pogłębienie dyskusji nad metodologią konstruowania wskaźników rozwoju społecznego, w celu wykorzystania ich w myśleniu o reformowaniu społeczeństw i planowaniu polityk publicznych. Rozdział ten zawiera liczne przykłady absurdalności fetyszyzowania wskaźnika wzrostu PKB. Kolejny rozdział nosi tytuł WARTość EKONOMICZNA CZASU WOLNEGO (s. 73-86) i zawiera oryginalny pomysł Autora na oszacowanie ekonomicznej ceny ludzkiego życia w wymiarze temporalnym. Ten zabieg myślowy ma na celu zmianę perspektywy w zarządzaniu z perspektywy mikroekonomicznej na perspektywę produktywności systemowej, z perspektywy korporacyjnych zysków na perspektywę jakości życia (s. 78). W rozdziale 4. OD WŁASNoścI INTELEKTUALNEJ DO ZARZĄDZANIA WIEDZA (s. 87-141) zagadnienie innowacji społecznej pojawia się w kontekście problemów własności intelektualnej. L. Dowbor przedstawia dwa przeciwstawne trendy, z których pierwszy jest korporacyjną próbą sprywatyzowania (dosłownie) wszystkiego z wynalaz- 
kiem ekonomii dostępu, a drugi jest ruchem otwartych licencji i wikinomii - ekonomii współpracy, przedsiębiorczości i kreatywności. Rozdział 5. SIEć ŚWIATOWEJ WŁADZY KORPORACYJNEJ (s. 143-155) zawiera przegląd badań nad siecią powiązań finansowych między globalnymi graczami korporacyjnymi, a także analizuje ich odpowiedzialność za wielki kryzys finansowy 2008. Rozdział 6. PRZeChWYTYWANIE WŁAdZY PRZEZ SYSTEM KORPORACYJNY (s. 157-177) ma za swój przedmiot pogłębiający i rozszerzający się antydemokratyczny wpływ korporacji na procesy polityczne przez przejmowanie władzy ustawodawczej, wykonawczej i sądowniczej. Dwa ostatnie rozdziały książki są szczególnie interesujące, dlatego że nie bazują wprost na DEMOKR ACJI EKONOMICZNEJ i są tekstami całkiem nowymi dla polskiego czytelnika. Rozdział 7. Pikettyzmy, Refleksje o Kapitale w XXI wieku zawiera rozbudowane odniesienie się Autora do książki T. Piketty'ego (2015). L. Dowbor docenia pracę T. Piketty’ego i włączą jej rezultaty do własnego myślenia o poszukiwaniu alternatywnych rozwiązań w zarządzaniu społecznym. Ostatni rozdział nosi tytuł EKonomia RODZINY: wSZYSTKIE NASZE DZIENNE SPRAWY; jest tłumaczeniem artykułu A Economia dA FA Mília (Dowbor, 2015) i stanowi zamknięcie wywodu L. Dowbora. Punktem wyjścia dla Autora jest codzienne życie. Po przejściu przez morza statystyk i sporów ekonomicznych Dowbor znów powraca do praktyki codziennego życia, na które wpływ mają globalne nierównowagi: społeczna i ekologiczna.

Styl pisarski L. Dowbora dobrze oddaje formuła „tonąc w statystykach”. Książka Co TO zA GRA? zawiera olbrzymie ilości danych, które rozproszone są w różnych źródłach - tu Autor zbiera je w jednym tekście i włącza do swojego myślenia o demokratyzowaniu gospodarki. Co ważniejsze, „dokumentują katastrofę" (s. 182) związaną z globalnym kapitalizmem już nie tylko organizacje, które znane są ze swojego lewicowego i antykapitalistycznego profilu, jak choćby OXFAM, ale już nawet Bank Światowy zdaje sobie sprawę z rozmiarów i szkodliwości globalnej nierównowagi społecznej i ekologicznej. Styl L. Dowbora jest buchalteryjny - w jego wywodzie jest strona "Winien” i strona „Ma”. Winien: „nieco realizmu” (s. 19). Ma: „innowacja społeczna” (s. 19). Winien: zmiana klimatyczna, globalne ocieplenie, nierówność w sferze dochodów, miliarderzy, spekulacje finansowe, synergia zagrożeń, gospodarka marnotrawstwa, prywatyzacja domeny publicznej, paradygmat konkurencji, absurdalna fetyszyzacja wskaźnika $\mathrm{PKB}$, gospodarka mytowa, eksternalizacja kosztów, sieć władzy korporacyjnej, kryzys finansów publicznych, obsceniczne poziomy nierówności, pułapka ubóstwa, finansjeryzacja gospodarki. Ma: inkluzja produkcyjna, kurs na racjonalność, paradygmat współpracy, nowe wskaźniki rozwoju społecznego, rozwój społeczeństwa obywa- 
telskiego, gospodarka wolnego dostępu, wolne licencje, wolne oprogramowanie, odzyskiwanie przestrzeni publicznej, punkt widzenia produktywności systemowej, wikinomia, uniwersalizacja dostępu, media ludowe, antyelitaryzm, reorganizacja zasobów, polityki publiczne, podatki od kapitału i fortun, pożyteczne utopie. Po stronie "Winien” w tym rachunku L. Dowbor umieszcza brak zdolności kapitalizmu do trafnej i racjonalnej alokacji zasobów, a po stronie „Ma” - ludzką kreatywność i przedsiębiorczość. Wszystko wskazuje na to, że stare problemy nie tylko nie mogą być rozwiązane przez kapitalizm, ale stają się jeszcze bardziej dotkliwe. Kapitalizm nie jest w stanie rozwiązać problemu biedy, głodu, seksizmu, rasizmu, nacjonalizmów i - jak pisze Autor, domagając się większej dozy realizmu - „[p]owinniśmy stanąć oko w oko z rzeczywistością. Wyklęty lud ziemi nie zniknie, budowa murów i zasieków nic nie załatwi, katastrofa klimatyczna nas nie ominie (...)" (s. 17). Przy tym wizja L. Dowbora nie jest pesymistyczna i stanowi przykład pedagogii nadziei i pedagogii możliwości - rozwiązania istnieją, ale trzeba wyjść poza zaklęty krąg reprodukcji ekonomicznej, wpierając alternatywne rozwiązania w zarządzaniu społecznym.

L. Dowbor proponuje, aby nie zostawiać ekonomii ekonomistom (s. 189) - konsekwencją tego postulatu jest konieczność myślenia o społecznych, politycznych, filozoficznych, psychologicznych i edukacyjnych konsekwencjach porządku ekonomicznego. Co TO ZA GRA? jest tym samym pozycją potencjalnie ważną dla osób związanych z pedagogiką i pedagogią: akademików, ale też nauczycieli, pedagogów społecznych czy lokalnych decydentów politycznych. L. Dowbor postuluje "globalny fiks” (s. 12-13): „Plan A” zawiódł pozostał „Plan B” i - jak pisze on w pracy O QUE É PODER LOCAL? - „Wiele z tych problemów będzie wymagać rozwiązań na poziomie narodowym lub globalnym. Niemniej chcemy podkreślić (...), co możemy zrobić na poziomie lokalnym, w naszym mieście, w naszej dzielnicy, w przestrzeni, gdzie ludzie mogą się zorganizować w celu zarządzania (...) jakością życia. Nie próbujemy tu sugerować, że wszystko można rozwiązać w ten sposób: władza lokalna jest potężnym instrumentem władzy, ale niewystarczającym" (Dowbor, 2008b, s. 5).

Ostatnią rzeczą, jaką należy docenić u L. Dowbora, jest jego otwarty stosunek do praw autorskich. Za deklaracjami idą czyny. Lwia część dorobku Autora książki Co TO ZA GRA?, wraz z recenzowaną pozycją, znajduje się do pobrania na stronie [dowbor.org].

\section{BIBLIOGRAFIA}

Dowbor, L. (1981). Brazylia bez egzotyki. Formowanie się kapitalizmu zależnego w Brazylii. Wrocław - Warszawa - Kraków - Gdańsk - Łódź: Zakład Narodowy im. Ossolińskich. 
Dowbor, L. (2005). Rozbita mozaika. Ekonomia poza równaniami. Warszawa: Wydawnictwo Akademickie Dialog.

Dowbor, L. (2008a). A organização de iniciativas locais. W: A. Martins (red.), Desafios da economia solidária (s. 59-84). São Paulo: Instituto Paulo Freire.

Dowbor, L. (2008b). O que é poder local?. Maszynopis. Pozyskano z: http://dowbor.org/ o8podlocal.doc, (data dostępu: 01.06.2017).

Dowbor, L. (2009). Demokracja ekonomiczna. Alternatywne rozwiązania w sferze zarzadzania społecznego. Warszawa: Instytut Wydawniczy Książka i Prasa.

Dowbor, L. (2015a). A Economia da Família. Psicologia USP, 26(1), 15-26. Pozyskano z: http:// dx.doi.org/10.1590/0103-6564D20140007, (data dostępu: 01.06.2017).

Freire, P. (1994). Pedagogia do Oprimido. Rio de Janeiro: Paz e Terra. Pozyskano z: dhnet.org. br/direitos/militantes/paulofreire/paulo_freire_pedagogia_do_oprimido.pdf, (data dostępu: 4.05.2017).

Freire, P. (2001). Política e Educação. São Paulo: Cortez. Pozyskano z: dhnet.org.br/direitos/ militantes/paulofreire/paulo_freire_politica_e_educacao.pdf, (data dostępu: 4.05.2017).

Gadotti, M. (2009). Economia solidária como práxis pedagógica. São Paulo: Instituto Paulo Freire.

Martins, A. (2008). Desafios da economia solidária. São Paulo: Instituto Paulo Freire.

Piketty, T. (2015). Kapitał w XXI wieku. Warszawa: Wydawnictwo Krytyki Politycznej.

Stańczyk, P. (2016). Ekonomia dla emancypacji: doktryny gospodarcze w Instytucie Paula Freirego. Forum Oświatowe, 28, 1(55), 55-76.

\section{SUMMARY}

\section{Pedagogy of Possibility in Economy, Ladislau Dowbor, Co TO ZA GRA? NOWE PODEJŚCIA DO EKONOMII, Książka i Praca, Warszawa 2017, pp. 253}

The main purpose of this text is to review new book of L. Dowbor. Co TO ZA GRA? is fourth book of the brazilian economist, published in Poland. The Review is written from the perspective of educational theory and economic conditions are considered as significant for educational processes in general, and educational emancipatory processes in specific. Reviewed book is an exceptional example of Freiran pedagogy of possibility in discourse of economy.

KEYWORDS: economic democracy, economy for emancipation, Ladislau Dowbor 